\title{
REPLACEMENT OF DIETARY YELLOW CORN BY WHEAT BRAN WITH OR WITHOUT MULTI-ENZYMES OR PREBIOTIC SUPPLEMENTATION ON NUTRIENT DIGESTIBILITY AND BLOOD PARAMETERS IN GROWING RABBITS
}

\author{
Hayam M. A. Abo El-Maaty ${ }^{1 *}$, Tork M. I. Dorra ${ }^{1}$, Gihan M. El Moghazy ${ }^{2}$ and Rana H. E. \\ Eid $^{2}$ \\ ${ }^{1}$ Department of Poultry Production, Faculty of Agriculture, Mansoura University, Mansoura 35516, \\ Egypt. \\ ${ }^{2}$ Regional Center for Food and Feed, Agricultural Research Center, Giza, Egypt. \\ *Corresponding author: hayam151@yahoo.com, Tel: +201008961731 Fax: +20502245268
}

(Received 5/6/2019, accepted 23/7/2019)

\section{SUMMARY}

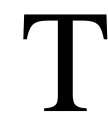

he present study was performed to investigate the influence of feeding diets contained three levels of yellow corn (YC) without or with enzymes and/or prebiotics on the nutrient digestibility and blood parameters of growing New Zealand White (NZW ) rabbits. A feeding trial $(3 \times 4)$ with factorial arrangement of treatment was carried out. The chemical analyses for experimental diets and faces and blood constituents were run. One hundred and eight, 6 weeks old weaning NZW rabbits were used in this study. Rabbits were randomly distributed into 12 equal experimental groups; each contained three equal replicates. The digestibility coefficients of dry matter (DM), organic matter $(\mathrm{OM})$, crude fiber $(\mathrm{CF})$, ether extract (EE), nitrogen free extract (NFE), non-ditrgant fiber (NDF), ADF and hemicellulose were increased with feeding on $15 \%$ YC diets than those of rabbits fed on $5 \%$ or $10 \%$ YC rations, but there was no significant effect of dietary treatments on DMI and CP digestibility. Rabbits fed enzyme-supplemented diets displayed significantly lower DM, OM, CF, EE, NFE, NDF, ADF and hemicellulose than those of other dietary treatments. There was no significant effect of these supplements on DMI (g/d) and CP digestibility, compared with the control diet (without supplements). The digestible DCP (\%), TDN\% and DEI (kcal/d) were significantly higher $(\mathrm{P} \leq 0.05)$ for animals fed diets containing $15 \%$ YC than feeding on 5 or $10 \%$ YC diets, while there were no significant effect on TDNI (g/d), CPI (g/d) and DEI (kcal/d). Rabbits fed the enzyme-supplemented diets exhibited significantly lower TDN (\%) and DE (kcal/kg) than did those fed other experimental diets. Similarly, significantly lower means of DEI $(\mathrm{kcal} / \mathrm{d})$ were recorded by rabbits fed enzyme- or enzyme plus prebiotics-supplemented diets compared with other experimental groups of rabbits, but DCP \% and CPI (g/d) were not affected. The plasma levels of triglycerides and total cholesterol were significantly lower for rabbits fed diets with $10 \%$ or $15 \%$ YC than those of rabbits fed the lowest level of YC, while there was no significant effect on ALT, AST, total protein or urea concentration. Rabbits fed the diets fortified with enzymes plus prebiotics exhibited significantly lower $(\mathrm{P} \leq 0.05)$ levels of plasma urea and triglycerides and significantly higher cholesterol concentration than did the control group. In conclusion, using YC to partially replace wheat bran in growing rabbits diets had no negative effect on the nutritive value of diets. The nutritive value of the experimental diets for growing rabbits could increase by supplementing enzymes plus prebiotics. The present study showed that feeding growing rabbits on diets contained $10 \% \mathrm{YC}$ without supplements or feeding on diets contained $15 \%$ YC with enzymes and prebiotics are effective for nutrient digestibility, nutritive value and health status of rabbits.

Keywords: Rabbits, digestibility, yellow corn (YC), blood status, enzymes and prebiotics.

\section{INTRODUCTION}

The meat of growing rabbit is low in cholesterol and has good protein. In developing countries, rabbit production is considered of economic importance. Several studies had shown that poor quality feeds, can be enhanced by addition of exogenous feed enzymes (Cowan et al., 1994).

Rabbits may also benefit from prebiotic feed additives to utilize their feed efficiently. However, the use of such feed additives has not been extensively studied in growing rabbits. Rabbit diets high in grain 
can cause overload in the hindgut leading to enteritis. Fiber is important for overall gut health and motility. The bacterial population in the hindgut allows rabbits to digest dietary non-starch polysaccharides (NSP) to some extent.

The digestibility of starch and NSP in grains is the current domain of developments in this area. Enzymes work on NSP causing their hydrolysis, decrease the viscosity of the contents inside gut, improve nutrient availability and improve the absorption of nutrients (Abo Egla et al., 2013). Several investigations have been attempted to improve nutrients digestibility by added enzymes. Eiben et al. (2004) tested the response to dietary supplementation with cellulase and got improvements in the feed conversion rate (FRC) and the mortality rate in rabbits weaned at the age of 23 days, while the average daily gain (ADG) remained unaffected. Increasing the digestibility of fiber is interesting. Bolis et al (1996) had demonstrated that adding cellulase and a multienzyme preparation (acid and neutral protease, $\beta$-glucanase, $\beta$-glycosidase, amyloglucosidase, pentosanase and xylanase) to rabbit diets led to significant improvements, in digestibility nutrients and they noticed some reductions in digestible and metabolizable energies and nitrogen balance in comparison with control diets.

Microbial fermentation of carbohydrates leads to the production of short chain fatty acids (SCFA). The SCFA limit growth of pathogenic microbes by decreasing caecal $\mathrm{pH}$. Dietary fiber plays an important role in the diet of rabbit because of its influence on caecal microbial activity (Gidenne et al., 2010). Dietary fiber level affects the digestibility of the nutrients in the diet and can also influence the growth rate of rabbits (Gidenne and Licois, 2005). The optimal dietary fiber level for growing rabbits is variable and may depend largely upon other factors such as type of fiber, age and breed of rabbit, and/or digestible energy content of the diet (Gidenne et al. 2010). In this context, the dietary crude fiber requirement recommended by the National Research Council (NRC, 1977) for normal growth of rabbits is $10-12 \%$. De Blas et al. (1986) concluded that a minimum of $10 \%$ dietary crude fiber is necessary for maximum growth rate of rabbits, while levels in excess of $17 \%$ depress growth by restricting energy intakes. De Blas and Mateos (2010) indicated that the dietary crude fiber requirement of intensively reared fattening rabbits is $15.5 \%$. The present study was performed to investigate the influence of feeding diets without or with enzymes, prebiotics or both on the nutrient digestibility, blood parameters of growing New Zealand White rabbits.

\section{MATERIALS AND METHODS}

The experimental work of the present study was carried out at the Poultry Research Unit, Agricultural Research and Experimental Center, Faculty of Agriculture, Mansoura University, while, the chemical analyses of experimental rations and feces, and procedures of blood analysis were run at the laboratory of Regional Center for Food and Feed, Agricultural Research Center, Cairo, Egypt.

\section{Experimental animals and management:}

One hundred and eight, 6 weeks old weaning New Zealand White (NZW) rabbits were used in this study. Rabbits were randomly distributed into 12 equal experimental groups; each contained three equal replications. Each replicate group (3 rabbits) was housed in a separate cage with the dimensions of $(50 \times 50 \times 45 \mathrm{~cm})$ for length, width and height, respectively. Rabbits were fed their respective experimental diets from 6 to 15 weeks of age. Feed and water were offered ad libitum throughout the experimental period. The mean values of live body weight (LBW) and feed intake (FI) were recorded on a replicate group basis and thus daily weight gain (DWG) and feed conversion (FCR) were also calculated.

\section{Feed supplements:}

In the present study, the multi-enzymeextra and prefect were performance in aquaculture and agriculture (KIOTECHAGIL). The specific wall stabilized enzymes combination of German origin (xylanase, Betaglucanase, Alpha amylase, protease and phytase). Prefect is a buffered blend of specific acids on a unique mineral carrier system combined with a fructo-oligosaccharide (FOS) to promote a healthy gut microflora.

\section{Experimental rations and design:}

An experiment was conducted with factorial arrangement of treatments $(3 \times 4)$, being three levels of yellow corn (YC) without or with enzymes, prebiotics or both. Thus, twelve experimental rations were formulated and used. The experimental groups of rabbits were fed their respective experimental rations in pelleted form. Three basal rations were used in this study; the first containing 5\% YC (R1), the second 
contained 10\% YC (R5) and the there'd 15\% YC (R9). The composition and calculated analysis of the basal diets are presented in Table (1), according to (NRC, 1977). Thus, twelve experimental rations were formulated and used, as follows:

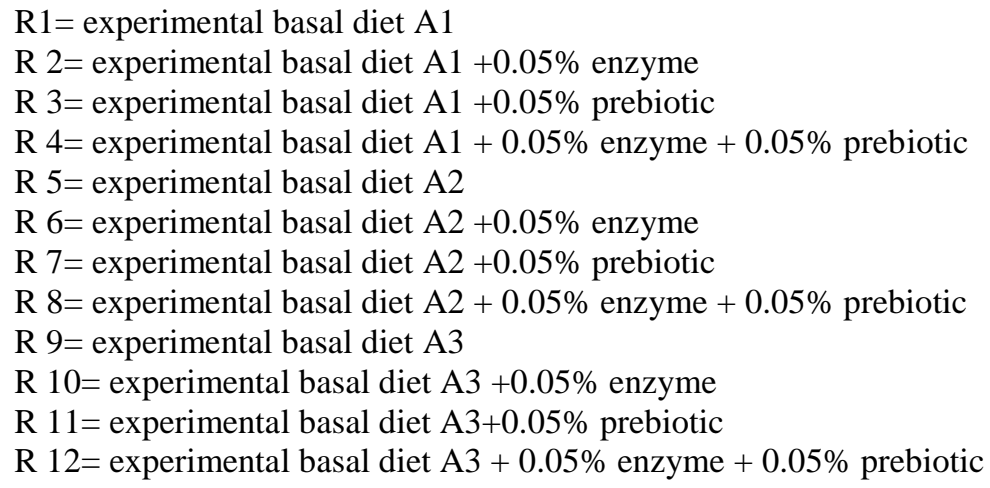

Table (1): Ingredients and chemical composition of the basal diets.

\begin{tabular}{|c|c|c|c|}
\hline \multirow[t]{3}{*}{ Feed ingredient } & \multicolumn{3}{|c|}{ Basal diet } \\
\hline & Diet1 (control) & Diet2 & Diet3 \\
\hline & $5 \% \mathrm{YC}$ & $10 \% \mathrm{YC}$ & $15 \% \mathrm{YC}$ \\
\hline Barley & 12 & 10 & 9 \\
\hline Yellow Corn & 5 & 10 & 15 \\
\hline Wheat bran & 35 & 30 & 25 \\
\hline Soybean meal, $44 \%$ & 7.5 & 8.5 & 9.5 \\
\hline Alfalfa hay & 35.7 & 36.7 & 36.7 \\
\hline Molasses & 2.0 & 2.0 & 2.0 \\
\hline Limestone & 1.0 & 1.0 & 1.0 \\
\hline Dicalcium phosphate & 1.2 & 1.2 & 1.2 \\
\hline Sodium chloride & 0.3 & 0.3 & 0.3 \\
\hline Vit. Min. premix & 0.3 & 0.3 & 0.3 \\
\hline Total & 100 & 100 & 100 \\
\hline \multicolumn{4}{|c|}{ Calculated analysis (as fed, NRC, 1977) } \\
\hline Digestible energy ( $\mathrm{Kcal} / \mathrm{kg})$ & 2597 & 2600 & 2615 \\
\hline Calcium $(\%)$ & 1.24 & 1.25 & 1.24 \\
\hline Total phosphorus (\%) & 0.77 & 0.74 & 0.70 \\
\hline Lysine $(\%)$ & 0.70 & 0.71 & 0.72 \\
\hline Methionine (\%) & 0.19 & 0.20 & 0.20 \\
\hline Methionine+cysteine (\%) & 0.50 & 0.50 & 0.51 \\
\hline \multicolumn{4}{|c|}{ Determined analysis (as DM, basis) } \\
\hline DM, \% & 89.62 & 90.37 & 90.53 \\
\hline OM, \% & 79.24 & 80.74 & 81.06 \\
\hline $\mathrm{CP}, \%$ & 16.39 & 16.08 & 16.97 \\
\hline $\mathrm{CF}, \%$ & 14.56 & 16.85 & 14.17 \\
\hline $\mathrm{EE}, \%$ & 2.15 & 2.39 & 2.44 \\
\hline NFE, $\%$ & 56.51 & 55.05 & 56.95 \\
\hline Ash, $\%$ & 10.38 & 9.63 & 9.47 \\
\hline NDF, $\%$ & 30.54 & 28.80 & 29.66 \\
\hline $\mathrm{ADF}, \%$ & 17.97 & 19.00 & 19.33 \\
\hline Hemicellulose, \% & 12.57 & 9.79 & 10.34 \\
\hline NFC, $\%$ & 42.37 & 42.34 & 44.27 \\
\hline
\end{tabular}

*Premix: Each $3 \mathrm{~kg}$ of the premix contained Vit A, $10.000000 \mathrm{IU}$; Vit D, $2000000 \mathrm{IU}$, Vit E, $10000 \mathrm{mg}$; Zinc, 3000 mg, Manganese, $2000 \mathrm{mg}$; Iron, $4000 \mathrm{mg}$; Copper, $1000 \mathrm{mg}$; Iodine, $100 \mathrm{mg}$; Selenium, $10 \mathrm{mg}$; Cobalt, $10 \mathrm{mg}$; Sodium, $23000 \mathrm{mg}$; Magnesium, $2000 \mathrm{mg}$ and $\mathrm{CaCo}_{3}$ : added to $3.0 \mathrm{~kg}$. 


\section{Digestibility trials:}

Three rabbits were chosen at the last week in a growth trial from each treatment with an average live body weight of about $2.0 \mathrm{~kg}$ and 14 weeks old to determine the digestibility coefficients of nutrients and feeding values of the tested rations. The FI and the total fecal output were separately recorded for each group for a 5-day period. Composite samples of each ration were taken for analysis at the beginning of experimental period. A composite sample from daily feces voided for each group was also taken. It was firstly dried at $60^{\circ} \mathrm{C}$ overnight, and then finally dried at $105^{\circ} \mathrm{C}$ for 3 hours.

\section{Chemical analysis and procedures:}

The official methods of the AOAC (1995) were used for determining the nutrient contents of feed and feces using triplicate samples of 1-2 g. Feed and feces samples were analyzed for Dry matter (DM), organic matter $(\mathrm{OM})$, crude protein $(\mathrm{CP})$ or nitrogen $(\mathrm{N})$, crude fiber $(\mathrm{CF})$, ether extract $(\mathrm{EE})$, ash, and fiber fractions, (non-ditrgant fiber (NDF) and ADF) and expressed on a dry matter basis. The factor 6.25 was used for calculating crude protein. The amount of nitrogen free extract (NFE) was obtained by the following equation:

$$
\mathrm{NFE} \%=[100-(\text { moisture } \%+\mathrm{Ash} \%+\mathrm{CP} \%+\mathrm{EE} \%+\mathrm{CF} \%)] .
$$

\section{VanSoest's method:}

Samples of rations and feces were also analyzed for fiber fractions (NDF, ADF ADL, hemi. and cell.) according to Goering and Van Soest (1970), by using Tecator Fibertic System.

\section{Calculation of total digestible nutrients (TDN) and digestible energy (DE) :}

The procedure and conversion factors for TDN reported by Cheeke et al. (1982) as: TDN $\%=\mathrm{DCP} \%+$ DCF\% + DNFE\% + DEE\% ×2.25.; while DE (kcal / kg DM) was calculated by the following equation according to Schiemann et al., $(1972):[\mathrm{DE}(\mathrm{kcal} / \mathrm{kg} \mathrm{DM})=(5.28 \times \mathrm{DCP})+(9.51 \times \mathrm{DEE})+(4.20 \times \mathrm{DCF})$ $+(4.20 \times$ DNFE $)]$.

\section{Blood Sampling and analysis:}

At the end of the experimental period, three rabbits from each experimental treatment were randomly chosen and slaughtered to examine certain blood parameters. Tow blood samples were collected from each rabbit and put into non-heparinized and heparinized test tubes. These blood samples were centrifuged at $4000 \mathrm{rpm}$ for 20 minutes and then stored at $-20^{\circ} \mathrm{C}$ until analysis for the different blood parameters. The plasma samples were used for determination of total proteins, (Doumas et al., 1981); triglycerides (Fossati, et al., 1980); urea-N, (Freidman et al., 1980) and cholesterol, (Allain et al., 1974) and aspartate aminotransferase (AST) and alanine aminotransferase (ALT), as described by using commercial kits..

\section{Statistical analysis:}

Statistical analysis of data was carried out using the General Linear Model Program of SAS (2000). Differences among means of treatments were identified by Duncan's Multiple Range Test (Duncan, 1955). The obtained data for nutrient digestibility and nutritive value of diets of different groups of rabbits were subjected to factorial analysis of variance according to the following mathematical model:

$$
Y_{i j k}=\mu+T_{i}+L_{j}+T L_{i j}+e_{i j k}
$$

Where; $Y_{i j k}=$ Observation of the tested factor, $\mu=$ Overall mean, $T_{i}=$ the effect of dietary $Y C$ level, $L_{j}=$ the effect of dietary supplements, $\mathrm{TL}_{\mathrm{ij}}=$ the interaction between dietary $\mathrm{YC}$ level and supplements and $\mathrm{e}$ $\mathrm{i} \mathrm{jk}=$ experimental random error.

\section{RESULTS AND DISCUSSION}

\section{Digestibility trials:}

Effect of the experimental diets on dry matter intake (DMI) and nutrient digestibility coefficients.

Effect of YC levels: 
Table (2) and Fig. 1 to 3 showed the means of dry matter intake, nutrient digestibility coefficients as affected by dietary YC levels and feed supplements. The digestibility coefficients of DM, OM, CF, EE, NFE, NDF, ADF and hemicellulose were increased $(\mathrm{P} \leq 0.05)$ with the highest level of YC $(15 \%)$ than those of rabbits fed on 5 or $10 \%$ YC rations, but there was no significant effect of dietary YC level on DMI and CP digestibility.

In this respect, the DM digestibility was lower in low starch diets than in high starch diets (Xiccato et al., 2002). Previous studies found that digestibility of YC starch are somewhat lower than barley starch (Blas et al., 1990). However, digestive problems can hardly be related to the major ileal starch overflow that results when rabbits are fed YC (Gidenne et al., 2000). They did not observe any significant difference in mortality or morbidity rate in rabbits receiving $\mathrm{YC}$, wheat bran or YC-wheat bran diets.

Table (2): Effect of dietary YC level supplemented with enzyme and/or prebiotic on dry matter intake and nutrient digestibility of the experimental rations.

\begin{tabular}{|c|c|c|c|c|c|c|c|c|c|c|}
\hline \multirow{2}{*}{ Treatment } & \multirow{2}{*}{ DMI } & \multicolumn{9}{|c|}{ Nutrient digestibility } \\
\hline & & $\mathrm{DM}$ & $\mathrm{OM}$ & $\mathrm{CP}$ & $\mathrm{CF}$ & $\mathrm{EE}$ & NFE & NDF & $\mathrm{ADF}$ & Hime. \\
\hline $\begin{array}{l}\text { YC levels \% (A): } \\
5 \%(\mathrm{~A} 1)\end{array}$ & 129.5 & $86.35^{\mathrm{b}}$ & $87.96^{\mathrm{b}}$ & 94.73 & $68.94^{\mathrm{c}}$ & $90.84^{\mathrm{b}}$ & $90.78^{\mathrm{b}}$ & $76.66^{\mathrm{b}}$ & $71.82^{\mathrm{b}}$ & $83.57^{\mathrm{b}}$ \\
\hline $10 \%(\mathrm{~A} 2)$ & 144.4 & $86.53^{\mathrm{b}}$ & $88.14^{\mathrm{b}}$ & 94.75 & $73.81^{\mathrm{b}}$ & $92.06^{\mathrm{b}}$ & $90.42^{\mathrm{b}}$ & $75.01^{\mathrm{b}}$ & $72.44^{\mathrm{b}}$ & $79.97^{\mathrm{b}}$ \\
\hline $15 \%(\mathrm{~A} 3)$ & 139.8 & $91.55^{\mathrm{a}}$ & $92.57^{\mathrm{a}}$ & 94.44 & $81.26^{\mathrm{a}}$ & $95.11^{\mathrm{a}}$ & $94.72^{\mathrm{a}}$ & $85.09^{\mathrm{a}}$ & $83.52^{\mathrm{a}}$ & $88.04^{\mathrm{a}}$ \\
\hline SEM & 8.23 & 0.65 & 0.57 & 0.77 & 1.47 & 0.66 & 0.45 & 1.22 & 1.30 & 1.28 \\
\hline Significance & NS & $* *$ & $* *$ & NS & $* *$ & $* *$ & $* *$ & $* *$ & $* *$ & $* *$ \\
\hline $\begin{array}{l}\text { Supplements (B): } \\
0.0 \% \quad \text { (B1) }\end{array}$ & 141.78 & $89.61^{\mathrm{a}}$ & $90.95^{\mathrm{a}}$ & 95.62 & $78.06^{\mathrm{a}}$ & $92.12^{\mathrm{b}}$ & $93.02^{\mathrm{a}}$ & $82.21^{\mathrm{a}}$ & $78.75^{\mathrm{a}}$ & $87.99^{\mathrm{a}}$ \\
\hline $0.05 \% \mathrm{E}(\mathrm{B} 2)$ & 131.96 & $84.26^{\mathrm{b}}$ & $86.12^{b}$ & 93.87 & $66.89^{b}$ & $90.96^{\mathrm{b}}$ & $88.96^{\mathrm{b}}$ & $71.84^{\mathrm{b}}$ & $68.40^{\mathrm{b}}$ & $77.36^{\mathrm{b}}$ \\
\hline $0.05 \% \mathrm{P}(\mathrm{B} 3)$ & 146.03 & $88.97^{\mathrm{a}}$ & $90.28^{\mathrm{a}}$ & 95.47 & $75.76^{\mathrm{a}}$ & $93.05^{\mathrm{ab}}$ & $92.58^{\mathrm{a}}$ & $79.85^{\mathrm{a}}$ & $77.59^{\mathrm{a}}$ & $83.79^{\mathrm{a}}$ \\
\hline $0.05 \% \mathrm{E}+0.05 \% . \mathrm{P}(\mathrm{B} 4)$ & 131.89 & $89.71^{a}$ & $90.87^{\mathrm{a}}$ & 93.61 & $77.96^{\mathrm{a}}$ & $94.57^{\mathrm{a}}$ & $93.33^{\mathrm{a}}$ & $81.78^{\mathrm{a}}$ & $78.97^{\mathrm{a}}$ & $86.28^{\mathrm{a}}$ \\
\hline SEM & 9.49 & 0.75 & 0.66 & 0.89 & 1.70 & 0.77 & 0.51 & 1.40 & 1.50 & 1.48 \\
\hline Significance & NS & $* *$ & $* *$ & NS & $* *$ & $* *$ & $* *$ & $* *$ & $* *$ & $* *$ \\
\hline AB Interaction: & & & & & & & & & & \\
\hline $\mathrm{A} 1 \mathrm{~B} 1=\mathrm{T} 1$ & 129.69 & 86.00 & 87.76 & 94.09 & 68.82 & 88.08 & 90.78 & 76.99 & 71.68 & 84.57 \\
\hline $\mathrm{A} 1 \mathrm{~B} 2=\mathrm{T} 2$ & 136.98 & 85.31 & 87.12 & 96.50 & 64.75 & 90.59 & 90.03 & 75.69 & 69.23 & 84.92 \\
\hline $\mathrm{A} 1 \mathrm{~B} 3=\mathrm{T} 3$ & 123.86 & 89.29 & 90.59 & 96.65 & 75.78 & 93.29 & 92.55 & 81.14 & 78.82 & 84.45 \\
\hline $\mathrm{A} 1 \mathrm{~B} 4=\mathrm{T} 4$ & 127.51 & 84.76 & 86.37 & 91.69 & 66.41 & 91.37 & 89.77 & 72.82 & 67.56 & 80.33 \\
\hline $\mathrm{A} 2 \mathrm{~B} 1=\mathrm{T} 5$ & 142.59 & 88.84 & 90.35 & 97.29 & 79.00 & 91.96 & 91.73 & 80.66 & 76.46 & 88.78 \\
\hline $\mathrm{A} 2 \mathrm{~B} 2=\mathrm{T} 6$ & 121.44 & 76.43 & 79.12 & 92.79 & 55.07 & 87.62 & 82.11 & 55.32 & 53.41 & 58.99 \\
\hline $\mathrm{A} 2 \mathrm{~B} 3=\mathrm{T} 7$ & 153.90 & 87.44 & 88.87 & 93.14 & 74.27 & 92.05 & 91.95 & 76.18 & 73.27 & 81.81 \\
\hline $\mathrm{A} 2 \mathrm{~B} 4=\mathrm{T} 8$ & 159.74 & 93.39 & 94.22 & 95.79 & 86.90 & 96.62 & 95.90 & 87.87 & 86.63 & 90.28 \\
\hline $\mathrm{A} 3 \mathrm{~B} 1=\mathrm{T} 9$ & 153.06 & 94.00 & 94.75 & 95.46 & 86.35 & 96.32 & 96.56 & 88.99 & 88.12 & 90.64 \\
\hline $\mathrm{A} 3 \mathrm{~B} 2=\mathrm{T} 10$ & 137.47 & 91.03 & 92.11 & 92.32 & 80.88 & 94.59 & 94.74 & 84.52 & 82.57 & 88.18 \\
\hline $\mathrm{A} 3 \mathrm{~B} 3=\mathrm{T} 11$ & 160.32 & 90.18 & 91.39 & 96.62 & 77.23 & 93.80 & 93.25 & 82.22 & 80.67 & 85.13 \\
\hline $\mathrm{A} 3 \mathrm{~B} 4=\mathrm{T} 12$ & 108.45 & 90.99 & 92.02 & 93.35 & 80.58 & 95.72 & 94.32 & 84.64 & 82.73 & 88.23 \\
\hline SEM & 16.45 & 1.30 & 1.14 & 1.54 & 2.95 & 1.33 & 0.89 & 2.43 & 2.61 & 2.56 \\
\hline Significance & NS & $* *$ & $* *$ & NS & $* *$ & $* *$ & $* *$ & $* *$ & $* *$ & $* *$ \\
\hline
\end{tabular}

$a-b:$ For each of the main effects, means within the same column with different superscripts differ significantly $(P \unlhd 0.05)$. SEM=standard error of means;NS: not significant; *: significant at $(P \unlhd 0.05)$; **: highly significant at $(P \unlhd 0.01)$

\section{Effect of feed supplements:}

As shown in Table (2) and Fig 4 to 6; the digestibility coefficients of DM, OM, CF, EE, NFE, NDF, $\mathrm{ADF}$ and hemicellulose and were increased $(\mathrm{P} \leq 0.05)$ with diet without any supplements (B1) or supplemented with prebiotics (B3) or with enzymes plus prebiotics (B4) than diet supplemented with enzymes (B2). There was no significant effect from these supplements on DMI (g/d) and CP digestibility, compared with the control diet (without supplements). Enzymes in the feed industry have been mostly 
been used for poultry to neutralize the effects of the viscous, non-starch polysaccharides in cereals such as barley, wheat, etc..., these anti-nutritive carbohydrates are undesirable, as they reduce digestion and absorption of all nutrients in the diet (Khattak et al., 2006). Benefits of using feed enzymes to poultry diets include; reduction of digesta viscosity, enhanced digestion and absorption of nutrients, especially fat and protein. The degree of improvement obtained by adding enzymes to the diet depends on many factors (Bedford, 1996).

Abo El-Maaty et al. (2018) reported that dietary prebiotic had a positive effect on the digestibility coefficients of DM, OM, CP, EE, CF and NFE of growing rabbits. They also noticed that added prebiotic had a positive effect on caecal fermentation activities of growing rabbits. They also found that the $\mathrm{pH}$ value, ammonia-N level, total bacteria and Lactobacillus counts of rabbits fed prebiotic-supplemented diets were significantly higher but $E$. coli count was reduced as compared to control ones. The reduction of the mortality during the fattening period with enzyme supplementation was associated with a decrease in ileal starch concentration that might limit the growth of the pathogenic flora (E.Coli and Clostridium) (Gidenne, 1992). Concurrent administration of Lactobacillus acidophilus, Streptococcus faecium and $S$. serevisia increases the digestibility of the diet (Kamra et al., 1996).

\section{Effect of dietary YC level by feed supplements interaction:}

There was no significant effect of the experimental treatments on DMI (g/d) and CP digestibility, while digestibility coefficients of DM, OM, CF, EE, NFE, NDF, ADF and hemicellulos were increased $(\mathrm{P} \leq 0.05)$ with feeding on the treatments designated as T8 and T9 than the other rations as shown in Table (2).

Wyatt and Goodman (1993) reported that YC-based diet exhibited better feed efficiency than those fed enzyme supplemented barley-based diets. Microbes also have the ability to metabolize xylan and pectin (De Blas and Gidenne, 1998). The products of this metabolism are their body proteins and byproducts of microbial fermentation refered to collectively as volatile fatty acids (VFA) such as acetic, propionic and butyric acids. These VFA are actively absorbed through the cecal and colonic wall and utilized by the rabbit as energy sources. Abo Egla et al. (2013) showed that supplementation of multienzyme or prebiotic containing into growing rabbits diet containing 30\% cucumber vines straw (CVS) significantly neutraliesed (similar to control) the adverse effects occurred by this feed material on all studied nutrient digestibility and nutritive values.

\section{Effect of experimental treatments on the feeding values of the experimental diets: Effect of YC levels:}

Table (3) showed the effect of dietary treatments on the feeding values of the experimental diets. As shown in Tables (3) and Fig. (7), means of TDN\% and DE $(\mathrm{kcal} / \mathrm{kg})$ were significantly $(\mathrm{P} \leq 0.05)$ increased in diet of $15,5 \%$ or $10 \%$ YC diets, while there were no significant effect on CPI (g/d) and DEI (kcal/d). The optimal content of starch in diets for growing rabbit ranges from 10 to $15 \%$ but may overpass $15 \%$ in the last phases of fattening (De Blas and Mateos, 2010).

\section{Effect of feed supplements:}

As shown in Table (3) and Fig (8), TDN \% and DE (kcal/kg) were significantly reduced for rabbits fed the enzyme-supplemented diets compared with other experimental groups. Starch digestion takes place, mainly in the small intestine, and the most important enzyme involved is pancreatic amylase. Amylase activity increases rapidly between weeks 2 and 7 of life (Gidenne et al., 2007) and is still increasing in 3-month-old rabbits. Similarly, the amyloglucosidase activity of the Jejunal mucosa generally increases between 37 and 60 days of age (Otutumi et al ., 2005). Undigested starch in the small intestine is in principle very quickly hydrolyzed and fermented by the microbiota in the caecocolic segment to lactate and volatile fatty acids. Stable high counts of amylolytic bacteria in the caecal contents of 2-7 weeks old rabbits have been reported (Padilha et al., 1995).

\section{Effect of interaction between dietary levels of YC and feed supplements:}

The interactions between dietary YC level and feed supplements were significant only for DE, TDN and DEI of rabbits, but other variable were not affected by the two main factors. Lockyer and Nugent (2017) and Xiccato et al., (2002) found that the DE concentration when the average starch to ADF ratio was 0.84 for low starch diet and 1.17 for high starch diets, respectively. The DE/DP ratio was similar in the two groups of diets and consistent with recommendations. Rabbits have a high feed intake $(65-80$ $\mathrm{g} / \mathrm{kg}$ body weight) and a rapid feed transit time (4-5 hours) and thus are able to consume lower quality forages and still meet their nutritional needs ( De Blas and Wiseman, 2003). Low energy diets also cause an increase in caecotrophs production and ingestion (Jenkins, 1999). Rabbits increase their amino acid intake from the consumption of their caecotrophs or soft feces. Thus their total protein intake is supplied by the dietary intake plus the ingestion of the soft feces. Preventing caecotrophy can reduce protein digestibility by as much as $20 \%$. The caecal microbiotas are able to use non-protein compounds (such as 
urea) and that caecotrophy helps to improve $\mathrm{N}$ digestion and retention. However, the studies also affirm that this extra $\mathrm{N}$ cannot compensate for a low dietary level or the use of low quality protein sources to meet growth requirements (Carabano et al., 2000). Current commercial levels of dietary protein for fatteners and reproductive does range from 16 to $18 \% \mathrm{CP}$. These levels exceed the recommendations in several circumstances, such as final phased of growth or lactation (Xiccato et al., 2006) .

Maintenance (2100-2200 kcal/kg) requirements comprise the majority of the rabbit's energy needs. Healthy rabbits will consume sufficient amounts of feed to meet their DE requirements. Rabbits will consume more feed if they are fed a low energy diet, and will consume less feed if they are fed a high energy diet. Increase in DE can affect the composition of body gain and the percentage of energy retained as protein and fat in the body (Jenkins, 1999). For growth, a wide range of protein and energy levels are needed, which may depend on slaughter weights or weaning age (De Blas et al., 1981 and Fraga et al. 1983). From these results, it was concluded that DE to digestible protein ratio is a more reliable unit as it has a higher and direct impact on body nitrogen and energy retention than the dietary content of fiber. Hence, the optimal level of crude protein in a diet depends on its digestibility and the DE content. A recommended ratio of $23.5 \mathrm{kcal} \mathrm{DE} / \mathrm{g}$ DP was suggested to optimize growth rate and mortality in growing rabbits.

Table (3): Effect of dietary YC level supplemented with enzyme and/or prebiotic on some digestible nutrients and feeding values of the experimental rations.

\begin{tabular}{|c|c|c|c|c|c|c|}
\hline \multirow{2}{*}{ Item } & \multicolumn{6}{|c|}{ Digestible nutrients and feeding values } \\
\hline & $\operatorname{DCP}(\%)$ & TDN $(\%)$ & TDNI $(g / d)$ & $\mathrm{CPI}(\mathrm{g} / \mathrm{d})$ & $\mathrm{DE}(\mathrm{kcal} / \mathrm{kg})$ & $\mathrm{DEI}(\mathrm{kcal} / \mathrm{d})$ \\
\hline \multicolumn{7}{|l|}{ YC levels \% (A): } \\
\hline $5 \%(\mathrm{~A} 1)$ & $15.53^{\mathrm{b}}$ & $81.27^{\mathrm{b}}$ & 105.24 & 20.15 & $2700.1^{\mathrm{b}}$ & 349.53 \\
\hline $10 \%(\mathrm{~A} 2)$ & $15.23^{\mathrm{b}}$ & $81.68^{\mathrm{b}}$ & 118.36 & 22.03 & $2710.2^{\mathrm{b}}$ & 392.89 \\
\hline $15 \%(\mathrm{~A} 3)$ & $16.03^{\mathrm{a}}$ & $86.70^{\mathrm{a}}$ & 121.38 & 22.40 & $2883.5^{\mathrm{a}}$ & 403.82 \\
\hline SEM & 0.13 & 0.67 & 7.02 & 1.29 & 25.83 & 23.44 \\
\hline Significance & $* *$ & $* *$ & NS & NS & $* *$ & NS \\
\hline \multicolumn{7}{|l|}{ Supplements (B): } \\
\hline $0.0 \%(\mathrm{~B} 1)$ & 15.77 & $84.72^{\mathrm{a}}$ & 120.48 & 22.39 & $2822.2^{\mathrm{a}}$ & $401.35^{\mathrm{a}}$ \\
\hline $0.05 \% \mathrm{E}(\mathrm{B} 2)$ & 15.47 & $80.30^{\mathrm{b}}$ & 106.25 & 20.40 & $2649.8^{\mathrm{b}}$ & $350.92^{\mathrm{a}}$ \\
\hline $0.05 \% \mathrm{P}(\mathrm{B} 3)$ & 15.74 & $84.11^{\mathrm{a}}$ & 122.96 & 23.00 & $2796.6^{\mathrm{a}}$ & $408.69^{b}$ \\
\hline $\begin{array}{l}0.05 \% \mathrm{E}+0.05 \% \mathrm{P} \\
(\mathrm{B} 4)\end{array}$ & 15.42 & $83.74^{\mathrm{a}}$ & 110.29 & 20.31 & $2789.6^{\mathrm{a}}$ & $367.36^{\mathrm{b}}$ \\
\hline SEM & 0.15 & 0.77 & 8.10 & 1.49 & 29.83 & 27.06 \\
\hline Significance & NS & $* *$ & NS & NS & $* *$ & $* *$ \\
\hline \multicolumn{7}{|l|}{ AB Interaction: } \\
\hline $\mathrm{A} 1 \mathrm{~B} 1=\mathrm{T} 1$ & 15.45 & 81.04 & 105.15 & 20.11 & 2697.7 & 349.73 \\
\hline $\mathrm{A} 1 \mathrm{~B} 2=\mathrm{T} 2$ & 15.81 & 80.51 & 110.26 & 21.67 & 2658.0 & 364.00 \\
\hline $\mathrm{A} 1 \mathrm{~B} 3=\mathrm{T} 3$ & 15.84 & 83.68 & 103.74 & 19.62 & 2786.4 & 345.47 \\
\hline $\mathrm{A} 1 \mathrm{~B} 4=\mathrm{T} 4$ & 15.03 & 79.85 & 101.82 & 19.18 & 2658.3 & 338.90 \\
\hline $\mathrm{A} 2 \mathrm{~B} 1=\mathrm{T} 5$ & 15.64 & 84.40 & 120.30 & 22.31 & 2809.6 & 400.44 \\
\hline $\mathrm{A} 2 \mathrm{~B} 2=\mathrm{T} 6$ & 14.92 & 74.12 & 89.96 & 18.17 & 2411.9 & 292.53 \\
\hline $\mathrm{A} 2 \mathrm{~B} 3=\mathrm{T} 7$ & 14.97 & 83.06 & 127.44 & 23.06 & 2777.7 & 425.90 \\
\hline $\mathrm{A} 2 \mathrm{~B} 4=\mathrm{T} 8$ & 15.40 & 85.14 & 135.74 & 24.62 & 2841.4 & 452.73 \\
\hline $\mathrm{A} 3 \mathrm{~B} 1=\mathrm{T} 9$ & 16.20 & 88.71 & 135.98 & 24.76 & 2959.4 & 453.87 \\
\hline $\mathrm{A} 3 \mathrm{~B} 2=\mathrm{T} 10$ & 15.67 & 86.28 & 118.55 & 21.37 & 2879.6 & 396.24 \\
\hline $\mathrm{A} 3 \mathrm{~B} 3=\mathrm{T} 11$ & 16.39 & 85.59 & 137.69 & 26.33 & 2825.7 & 454.72 \\
\hline $\mathrm{A} 3 \mathrm{~B} 4=\mathrm{T} 12$ & 15.84 & 86.23 & 93.30 & 17.14 & 2869.1 & 310.45 \\
\hline SEM & 0.26 & 1.83 & 14.03 & 2.58 & 51.66 & 46.87 \\
\hline Significance & NS & $* *$ & NS & NS & $* *$ & $* *$ \\
\hline
\end{tabular}




\section{Effect of feeding the experimental diets on some blood parameters:}

\section{Effect of dietary YC levels:}

Table (4) and Fig. (9) showed the blood constituents as affected by dietary YC level and feed additives to growing rabbits.. The blood plasma levels of triglycerides was significantly higher increased $(\mathrm{P} \leq 0.05)$ with feeding on $5 \%$ than with feeding on $10 \%$ or $15 \% \mathrm{YC}$ in the diet, while there was no significant effect of dietary treatments on ALT and AST or total protein or urea concentrations. Rabbits fed the diets of 5 or $10 \%$ YC displayed significantly higher $(\mathrm{P} \leq 0.05)$ levels of plasma cholesterol than did those fed the $15 \%$ YC-diets.

Table (4): Effect of dietary YC levels supplemented with enzyme and/or prebiotic on some blood constituents of growing rabbits.

\begin{tabular}{|c|c|c|c|c|c|c|}
\hline Item & $\begin{array}{l}\text { ALT } \\
\text { (U/L) }\end{array}$ & $\begin{array}{l}\mathrm{AST} \\
(\mathrm{U} / \mathrm{L})\end{array}$ & $\begin{array}{c}\text { Total } \\
\text { protein } \\
(\mathrm{g} / \mathrm{dl})\end{array}$ & $\begin{array}{l}\text { Urea } \\
(\mathrm{mg} / \mathrm{dl})\end{array}$ & $\begin{array}{c}\text { Triglycerides } \\
(\mathrm{mg} / \mathrm{dl})\end{array}$ & $\begin{array}{l}\text { Total } \\
\text { chol. } \\
(\mathrm{mg} / \mathrm{dl})\end{array}$ \\
\hline \multicolumn{7}{|l|}{ YC levels \% (A): } \\
\hline $5 \%(\mathrm{~A} 1)$ & 31.83 & 46.92 & 5.19 & 28.58 & $130.95^{\mathrm{a}}$ & $58.55^{\mathrm{a}}$ \\
\hline $10 \%(\mathrm{~A} 2)$ & 35.58 & 43.42 & 5.16 & 27.71 & $115.58^{\mathrm{b}}$ & $63.63^{\mathrm{a}}$ \\
\hline $15 \%(\mathrm{~A} 3)$ & 33.67 & 40.00 & 4.87 & 29.20 & $101.80^{\mathrm{c}}$ & $52.92^{\mathrm{b}}$ \\
\hline SEM & 1.78 & 2.48 & 0.21 & 1.25 & 3.79 & 1.82 \\
\hline Significance & NS & NS & NS & NS & $* *$ & $* *$ \\
\hline \multicolumn{7}{|l|}{ Supplements (B): } \\
\hline $0.0 \% \quad$ (B1) & 36.67 & 41.22 & 5.22 & $30.96^{\mathrm{a}}$ & $127.11^{\mathrm{a}}$ & $53.73^{\mathrm{b}}$ \\
\hline $0.05 \% \mathrm{E}(\mathrm{B} 2)$ & 34.22 & 46.00 & 5.96 & $28.79^{\mathrm{ab}}$ & $119.9^{\mathrm{ab}}$ & $57.73^{\mathrm{b}}$ \\
\hline $0.05 \% \mathrm{P}(\mathrm{B} 3)$ & 31.33 & 46.44 & 4.96 & $28.49^{\mathrm{ab}}$ & $107.28^{\mathrm{b}}$ & $56.61^{\mathrm{b}}$ \\
\hline $0.05 \% \mathrm{E}+0.05 \% \mathrm{P}(\mathrm{B} 4)$ & 32.56 & 40.11 & 5.16 & $25.76^{\mathrm{b}}$ & $110.16^{\mathrm{b}}$ & $65.38^{\mathrm{a}}$ \\
\hline SEM & 2.05 & 0.24 & 0.24 & 1.44 & 4.38 & 2.10 \\
\hline Significance & NS & NS & NS & $*$ & $* *$ & $* *$ \\
\hline \multicolumn{7}{|l|}{ AB Interaction: } \\
\hline $\mathrm{A} 1 \mathrm{~B} 1=\mathrm{T} 1$ & 38.67 & 44.67 & 5.77 & 34.50 & 149.77 & 71.83 \\
\hline $\mathrm{A} 1 \mathrm{~B} 2=\mathrm{T} 2$ & 33.00 & 49.00 & 5.23 & 29.53 & 143.03 & 67.10 \\
\hline $\mathrm{A} 1 \mathrm{~B} 3=\mathrm{T} 3$ & 30.67 & 53.33 & 4.77 & 26.77 & 120.77 & 41.23 \\
\hline $\mathrm{A} 1 \mathrm{~B} 4=\mathrm{T} 4$ & 25.00 & 40.67 & 5.00 & 23.53 & 110.23 & 54.03 \\
\hline $\mathrm{A} 2 \mathrm{~B} 1=\mathrm{T} 5$ & 34.33 & 40.33 & 5.07 & 29.60 & 144.60 & 48.67 \\
\hline $\mathrm{A} 2 \mathrm{~B} 2=\mathrm{T} 6$ & 33.33 & 48.67 & 4.73 & 28.17 & 104.80 & 61.17 \\
\hline $\mathrm{A} 2 \mathrm{~B} 3=\mathrm{T} 7$ & 36.00 & 38.67 & 5.33 & 28.77 & 95.20 & 74.10 \\
\hline $\mathrm{A} 2 \mathrm{~B} 4=\mathrm{T} 8$ & 38.67 & 46.00 & 5.50 & 24.30 & 117.73 & 70.57 \\
\hline $\mathrm{A} 3 \mathrm{~B} 1=\mathrm{T} 9$ & 37.00 & 38.67 & 4.38 & 28.77 & 86.97 & 40.70 \\
\hline $\mathrm{A} 3 \mathrm{~B} 2=\mathrm{T} 10$ & 36.33 & 40.33 & 4.90 & 28.67 & 111.87 & 44.93 \\
\hline $\mathrm{A} 3 \mathrm{~B} 3=\mathrm{T} 11$ & 27.33 & 47.33 & 4.77 & 29.93 & 105.87 & 54.50 \\
\hline $\mathrm{A} 3 \mathrm{~B} 4=\mathrm{T} 12$ & 34.00 & 33.67 & 4.97 & 29.43 & 102.50 & 71.53 \\
\hline SEM & 3.55 & 4.76 & 0.42 & 2.49 & 7.58 & 3.64 \\
\hline Significance & NS & NS & NS & NS & $* *$ & $* *$ \\
\hline
\end{tabular}

\section{Effect of feed supplements:}

As shown in Table (4) and Fig. (10), blood plasma was significantly lower urea concentration in rabbits fed the diets supplemented with enzymes plus prebiotics compared with other experimental diets. However, level of plasma cholestrerol was significantly higher $(\mathrm{P} \leq 0.05)$ in rabbits fed the enzyme plus prebiotic supplemented diets compared with other dietary treatments. There was a significant decrease in plasma levels of triglycerides due to feeding the diets supplemented with prebiotics- or enzyme plus prebiotics compare with other treatments. 


\section{Effect of interaction between dietary YC level and feed supplements:}

The interactions between dietary YC level and feed supplements were significant only for blood plasma concentrations of total cholesterol and triglycerides (TG) but other blod parameters were not affect by the interaction between the two dietary factors.. Blood examination gives the opportunity to investigate the presence of several metabolites and other constituents and helps detect conditions of stress, which can be nutritional, environmental or physical (Aderemi, 2004). Aspartate aminotransferase and alanine aminotranferase values overlapped those reported by other authors in laboratory rabbits (Wolford et al. 1986). Proper nutrition is one of the important aspects of broiler rabbit production (Sinha et al., 2008). The protein and energy contents of the diet play a vital role in rabbit nutrition. Biochemical characterization physiology and metabolic process of rabbit will help in better understanding of rabbit in relation to growth and meat. The increase in total serum cholesterol level might be due to increase in its synthesis or reduction of its catabolism (West et al., 1966). Triglyceride is transported in blood via macromolecular particles called lipoprotein.

Chylomicrons and very low- density lipoprotein (VLDL) are the predominant carriers of TG and are often referred to lipoprotein (Kleppe et al., 1988). It is well established that liver regulated plasma levels of cholesterol and TG by secretion and transport of these lipids in the VLDL and by removal of lipoproteins by receptor-mediated endocytosis and changes in nutritional and hormonal statues which alter the rate of assembly and secretion of VLDL particles (Thomas et al., 1992). Insulin inhibits breakdown of fat in adipose tissue by inhibiting the intracellular lipase that hydrolyses TG to release fatty acids. Insulin facilitates entry of glucose into adipocytes, and within those cells, glucose can be used to synthesize glycerol. This glycerol along with the fatty acids delivered from the liver, is used for synthesis TG within the adipocyte. By these mechanisms, insulin is involved in further accumulation of TG in fat cells. Low insulin facilitates lipolysis while high insulin stimulates de novo lipogenesis (Rommers et al., 2004). In conclusion, using YC to partially replace wheat bran in rabbit ration had no negative effect on the nutritive value of diets. The nutritive value of the experimental diets for growing rabbits can increase by supplementing their diets with enzymes plus prebiotics. The present study showed that feeding growing rabbits on diets contained $10 \%$ YC without supplements or feeding on diets contained $15 \%$ YC supplemented with enzymes and prebiotics are effective for regard to nutrient digestibility, nutritive value and health status of rabbits.

\section{ACKNOWLEDGEMENT}

This study was performed at Faculty of Agriculture, Mansoura University, Egypt. We would like to thank everyone helped us.

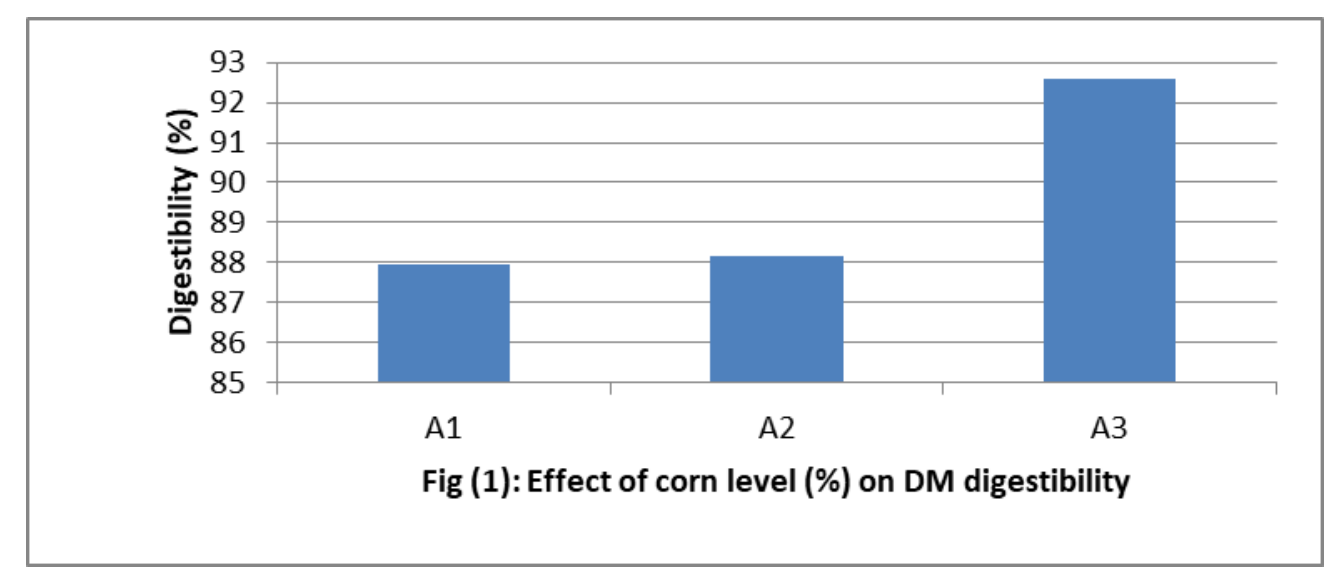


Abo El-Maaty et al.
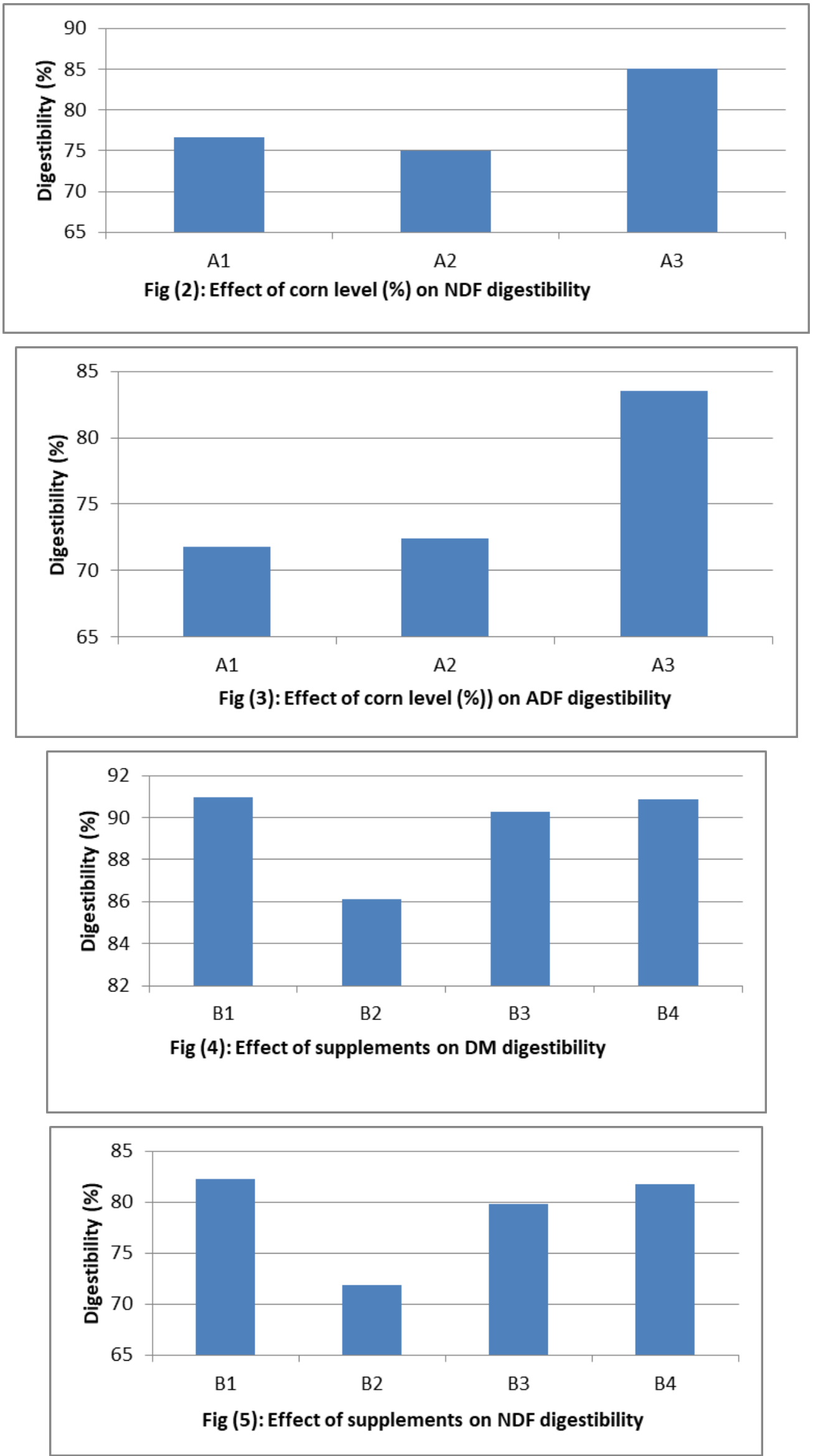
Egyptian J. Nutrition and Feeds (2019)
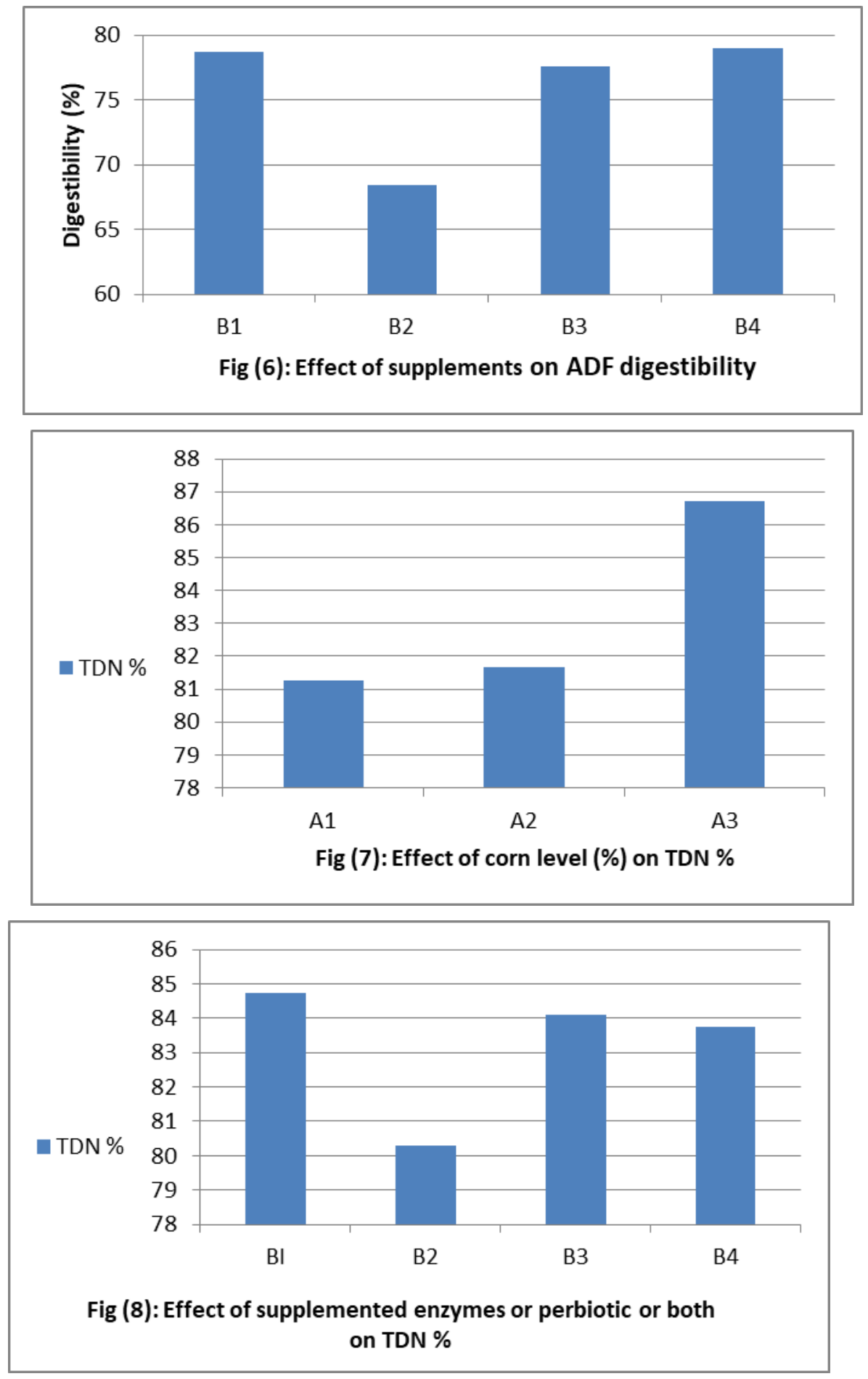
Abo El-Maaty et al.
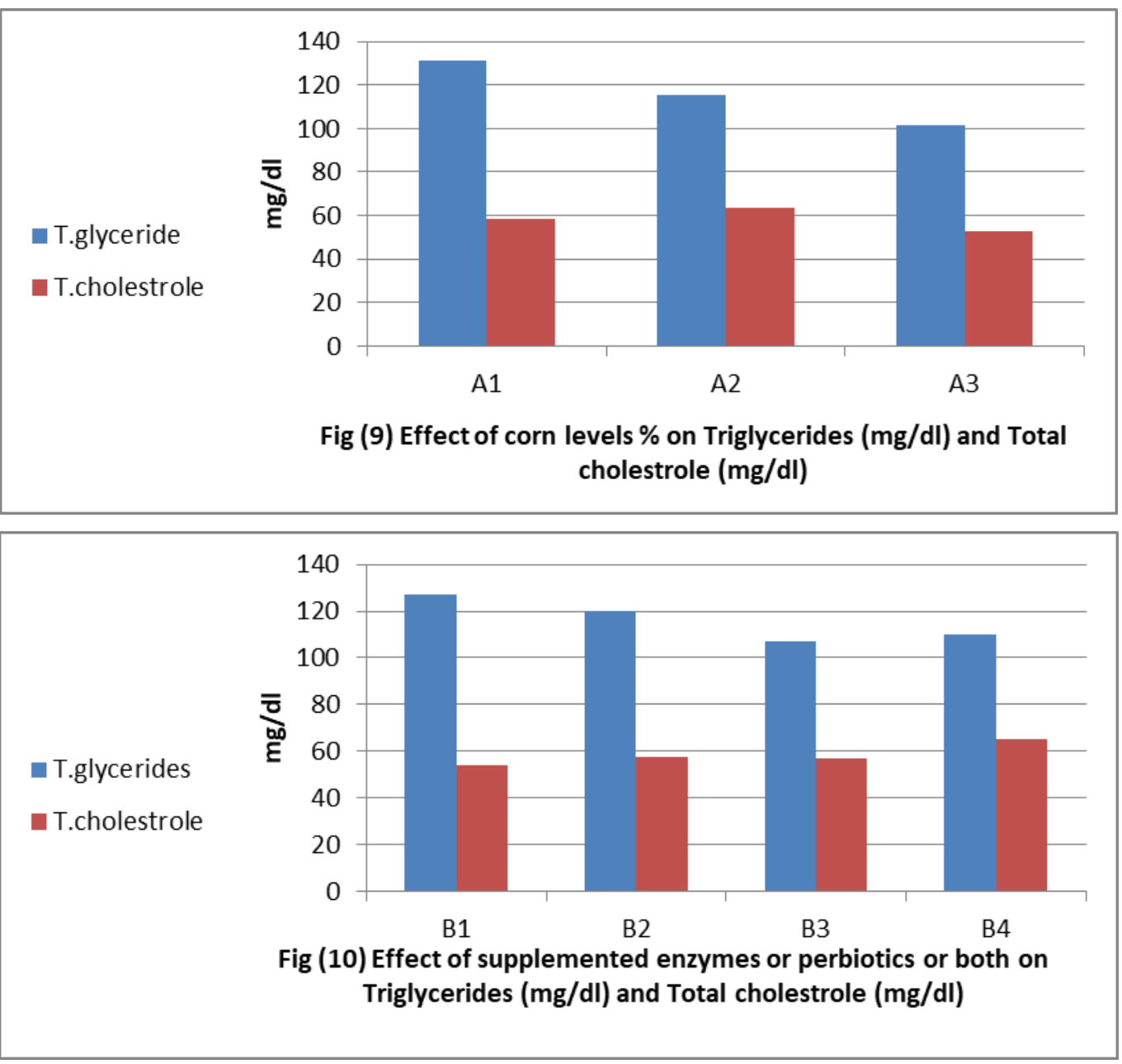

\section{REFERENCES}

Abo Egla, El-Samra H. A.; Hayam M.A. Abo El-Maaty; E.M. Qota; Sheren M. El-Desouky (2013). Effects of replacing clover hay by cucumber (Cucumis sativus L.) vines straw without or with Natuzyme or prebiotic containing mannan oligosaccharide in NZW rabbit diets on nutrient digestibility, caecal, carcass characteristics and some blood constituents. J. Anim. Poult. Prod., Mansoura Univ., 4(2): 79-96.

Abo El-Maaty, Hayam M. A.; Sara Kh. Sherif and Lina S. A. Foda (2018). Dietary Sugar Beet Tops and Prebiotic Effect on Nutrient Digestibility, Caecal Activity and Organ Histology of Weaning Rabbits. J. of Agric. Sci.; Vol. 10 (3). doi:10.5539/jas.v10n3p162

Aderemi; F. A. (2004). Effects of replacement of wheat bran with cassava root sieviate supplemented or unsupplemented with enzyme on the hematology and serum biochemistry of pullet chicks. Trop. J. Anim. Sci., 7: 147.

Allain, C. C.; L. S. Poon; C. S. Chan; W. Richmond and P. C. Fu (1974). Enzymatic determination of total serum cholesterol. Clin. Chem., 20: 470.

AOAC (1995). Official methods of analysis $\left(13^{\text {th }}\right.$ Ed). Association of Official Analytical Chemists. Washington, DC, USA.

Bedford, M. R. (1996). The effect of enzymes on digestion. J. of Applied Poult. Res., 5: 370.

Blas, E.; J. C. Fandos; C. Cervera; T. Gidenne and J. M. Perez (1990). Effect de la nature et du taux d' amidon sur l'utilisation digestive de la ration chez le lapin au cours de la croissance. In: Proceedings 
5èmes Journeés de la Recherche Cunicole, en france, paris, France December 1990, Vol. 2. Comm. no. 50 .

Bolis, S.; C. Castrovilli; M. Rigoni; D. Tedesco and F. Luzi (1996). Effect of enzymes addition in diet on protein and energy utilization in rabbit .In proc.: $6^{\text {th }}$ World Rabbit Congress, Toulouse, France, III.

Carabano, R.; C. De Bias and A. I. Gracia (2000). Recent advances in nitrogen nutrition in rabbits, World Rabbit Sci., 8:14.

Cheeke, P.R.; N.M. Patton and G.S. Tempelton (1982). Rabbit Production. 5th Ed. Interstate Printers and publishers, USA.

Cowan, W.D.; A. Korsbak; T. Hastrup and P.B. Rasmussen (1994): Influence of added microbial enzymes on energy and protein availability of selected feed raw materials. Proceedings of the XV Western Nutrition Conference, Winnipeg, Manitoba, pp. 143-152

De Blas, J. C. and T. Gidenne (1998). Digestion of sugars and starch In: De Blas, C., Wiseman, J. editors 1998. The Nutrition of the Rabbit allingford: CABI publishing P 19.

De Blas, J. C. and J. Wiseman (2003). The Nutrition of the Rabbit. CABI publishing, Oxon, UK.

De Blas, J. C.; E. Perez; M. J. Fraga; J. M. Rodriguez and J. F. Galvez (1981). Effect of diet on feed intake and growth of rabbits from weaning to slaughter at different ages and weights. J. Anim. Sci., 52:1225.

De Blas, J. C.; G. Stantoma; R. Carabano and M. J. Fraga (1986). Fiber and starch level in fattening rabbit diets. J. Amin. Sci., 63: 1897.

De Blas, J.C. and G.G. Mateos (2010). Feed formulation, In: Nutrition of the rabbit, $2^{\text {nd }}$ ed. Edited by De Blas, J.C. and J. Wiseman. CABI publishing, Wallingford, U.K.: $222-232$

Doumas, B. T.; D. D. Carter; R. J. Peters and T. R. Schaffer (1981). A candidate reference method for determination of total protein in serum. Development and Validation. Clin. Chem., 27: 1642.

Duncan, D. B., (1955). Multiple Range and Multiple F Test. Biometrics, 11: 1 - 24.

Eiben, C.S.; M. Mezes; N. Zijarto; K. Kustos; K. Godor-Surmann and M. Erdelyi (2004). Dose dependent effect of cellulose supplementation on performance of early weaned rabbit. In Proc. $8^{\text {th }}$ world Rabbit Congress, Puebla, Mexico, 799.

Fossati, P.; L. Prencipe and G. Berti (1980). Use of 3,5-dichloro-2- hydroxybenzenesulfonic acid/4aminophenazone chromogenic system in direct enzyme assay of uric acid in serum and urine. Clin. Chem., 26:227.

Fraga, M. J.; J.C de-Bias; E. Perez; J. M. Rodriguez; C.J. Perez and J.F. Galvez (1983). Effect of diet on chemical composition of rabbits slaughtered at fixed body weights. J. Anim. Sci., 56:1097.

Freidman, R. B.; R. E. Anderson; S. M. Entire and S. B. Hinsberg (1980). Clin. Chem. 26.

Gidenne T.; V. Pinheiro and L. Falcaö̈e Cunha (2000). A comprehensive approach of the rabbit digestion: consequences of a reduction in dietary fibre supply. Livestock Sci. 64 (2): 225.

Gidenne, T. (1992). Effect of fiber level, particle size and adaptation period on digestibility and rate of passage as measured at the ileum and in the faeces in the adult rabbit. Br. J. Nutr., 67: 133.

Gidenne, T.; R. Carabano; J. Garcia and C. D. Blas (2010). Fiber digestion. In: De Blas, C., Wiseman, J. (Ed.), Nutrition of the rabbit. CABI, P. 179.

Gidenne, T.; L. Debray; L. Fortun-lamothe and I. Le Huerou-Luron (2007). Maturation of the intestinal digestion and microbial activity in the young rabbit: impact of the dietary fiber:starch ratio. Comparative Biochemistry and physiology part A 148:834.

Gidenne, T. and D. Licois (2005). Effect of a high fibre intake on the resistance of the growing rabbit to an experimental inoculation with an enteropathogenic strain of Escherichia coli. Anim. Sci., 80: 281 288.

Goering, K. K. and P. J. Van Soest (1970). Forage Fiber Analysis. Agric. Handbook, No. 379, USDA, Washington, DC.

Jenkins, J. R. (1999). Feeding recommendations for the horse rabbit: veterinary clinics of North America: Exotic Animal practice. Vol. (2):143. W.B. Saunders Company, Philadelphia. 
Kamra, D. N.; L. C. Chaudhary; R. Singh and N.N. Pathak (1996). Influence of feeding probiotics on the growth performance and digestibility in rabbits. World Rabbit, Sci. 4 (2):85.

Khattak, F. M.; T. N. Pasha; Z. Hayat and A. Mahmud (2006). Enzymes in poultry nutrition. J. Anim. Poult. Sci. 16 (1-2).

Kleppe, B. B.; R. J. Aiello; R. R. Grummer and L. E. Armentano (1988). Triglyceride accumulation and very low density lipoprotein secretion by rat and goat hepatocytes in vitro J. Dairy Sci., 71:1813.

Lockyer, S. and A. P. Nugent (2017). Health effects of resistant starch. Nutr. Bull., 42: 10.

NRC (1977). Nutrient requirement of rabbits. Nutritional Academic of Sciences, Nutritional Research Council, Washington, DC., USA.

Otutumi, L. K.; A. C. Furlan; C. Scapinello; E. N. Martins; R.M. Peralta; D.L. Souza and M.L.R. Santolin (2005). Digestiblidade e atividade enzimatica intestinal de coelhos em crescimento alimentados com differentes fontes de amido procesadas ou nao por extrusao. Revista Brasileira de zootecnia 34, 557.

Padilha, M. T. S.; D. Licois; T. Gidenne; B. Carre and G. Fonty (1995). Relationships between microflora and caecal fermentation in rabbits before and after weaning. Reproduction Nutrition Development, 35 (4):375.

Rommers, J. M.; C. Boiti; G. Brecchia; R. Meijerhof; J. P. T. M. Noordhuizen; E. Decuypere and B. Kemp (2004). Metabolic adaptation and hormonal regulation in young rabbits does during long-term caloric restriction and subsequent compensatory growth. Anim. Sci., 79: 255.

SAS (2000). Statistical Analysis System / STAT User's Guide, release 6.03. Ed., SAS Institute. Inc., Cary, Nc. USA, PP. 125.

Schiemann, R.; K. Nehring; L. Hoffmann; W. Jentsch and A. Chudy (1972). Energetische Futterbewertung und Energienormen. VEB Deutscher Landwirtschafts Verlag, Berlin, pp. 72.

Sinha, K.P.; R.L. Prasad and A. Adil (2008). Blood biochemical profile in relation to carbohydrate and lipid metabolism in rabbit. Veterinary, World, Vol. 1(1).

Thomas, V.F.; I. Cagen; H.C. Wilcox and M. Heimberg (1992). Regulation of hepatic secretion of very low density lipoprotein by cholesterol. J. Lipid Res. 33:179.

West, F.S.; Todd, W.R.; H.S. Masen and J.T. Van Bruggn (1966). Text book of Biochemistry. $4^{\text {th }}$ edition, MacMillan, New York.

Wolford, S., T.; R. A. Schroer; F. X. Gohs; P. P. Gallo; M. Brodeck; H. B. Falk and R. Ruhren (1986). Reference range data base for serum chemistry and hematology values in laboratory animals. Journal of Toxicology and Environmental Health 18: 161.

Wyatt, C.I. and T. Goodman (1993). Utilization of feed enzymes in laying hen rations. Journal of Applied poultry Research. 2: 68.

Xiccato, G.; A. Trocino and N. Nicodemus (2006). Nutrition of the young and growing rabbit: a comparative approach with the doe. In: Maertens, L., Coudert, P. (ed) Recent advances in rabbit science. IIVO, Merelbeke, Belgium, 239.

Xiccato, G.; A. Trocino; A. Sartori and P. I. Queaque (2002). Effect of dietary starch level and source on performance, caecal fermentation and meat quality in growing rabbits. World Rabbt Science, Vol. 10 (4):147. 
إحلال الذره الصفرا محل نخالة القمح مع أو بدون مخلوط إنزيمات أو منشط نمو حيوى على معاملات هضم

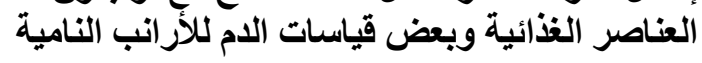

\author{
هيام تحما أبو المعاطي1 ، ترك محم إبراهيم دره1 ، جيهان محمد المغازي² و رنا حسين الثنافعي عيد² \\ اقسم إنتاج الدواجن - كلية الزراعة - جامعة الدنصورة - المنصورة- مصر. \\ 2المركز الإقليمي للاغغنية والأعلاف - مركز البحوث النزراعية - وزارة النزراعة - مصر.
}

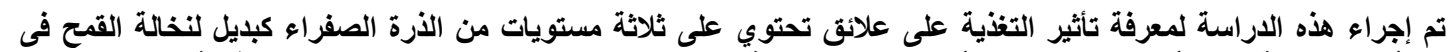

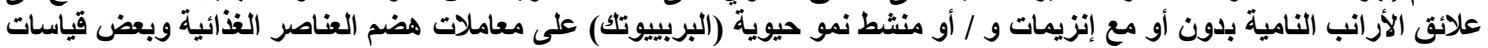

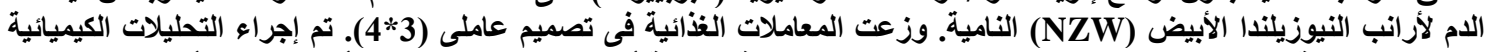

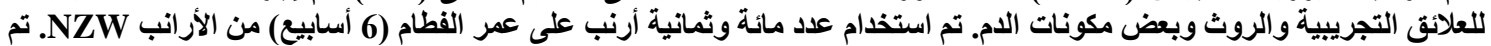

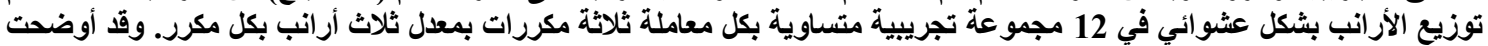

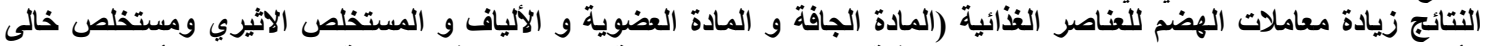

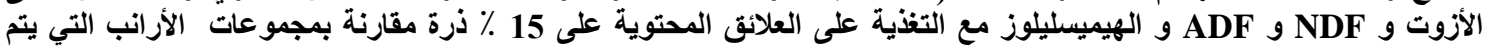

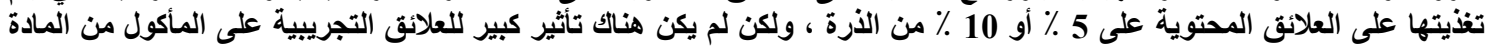

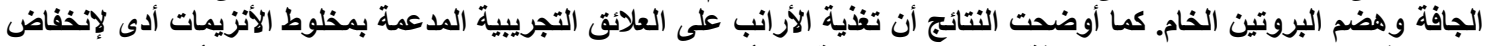

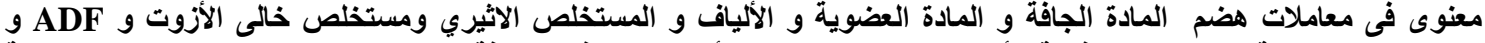

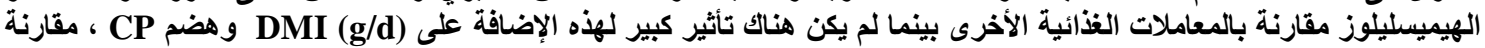

مع باقى المعاملات التجريبية.

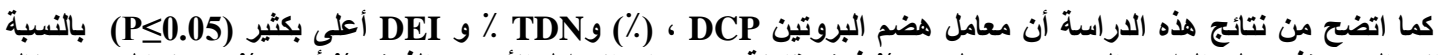

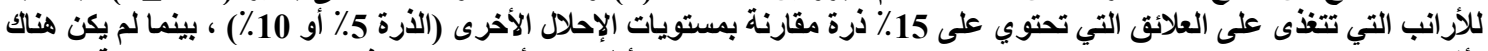

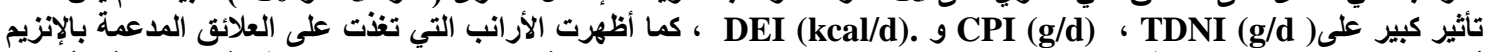
أداء منخفض بشكل ملحوظ في معامل هضم

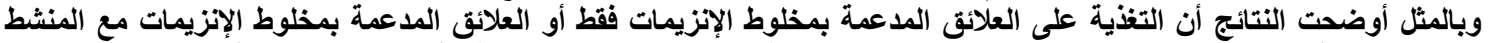

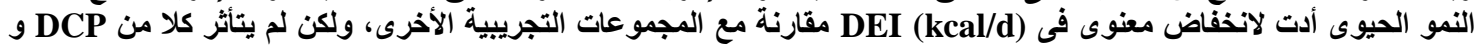

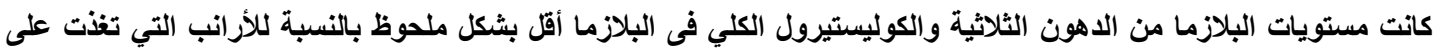

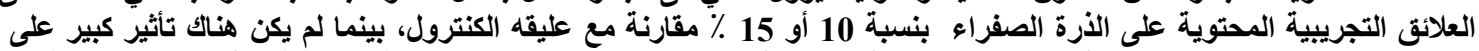

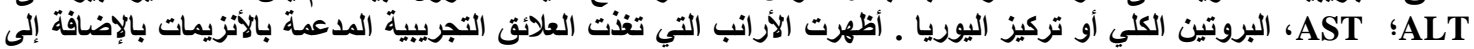

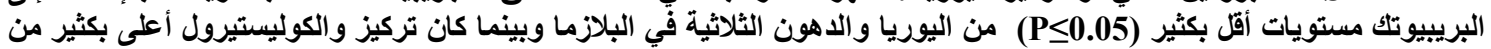
مجموعة الكنترول

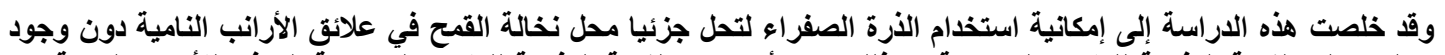

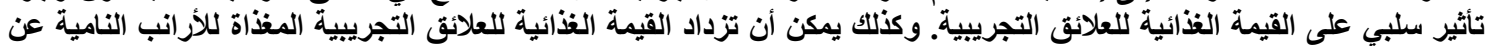

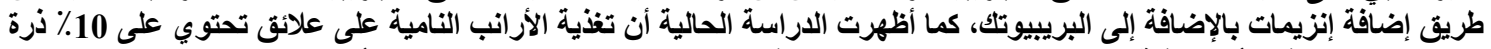

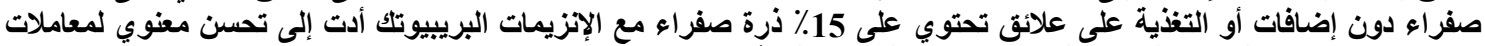
هضم العناصر الغذائية والقيمة الغذائية للعلائق والحالة الصحية للأرانب. 